\title{
DESIGN OF A FUZZY CONTROLLER FOR SOLAR PV ARRAY FED WATER PUMPING SYSTEMS
}

\author{
RUAA R. SAFAALDEEN and LOKMAN H. HASSAN \\ Dept. of Electrical and Computer Engineering, College of Engineering, University of Duhok, \\ Kurdistan Region- Iraq
}

(Received: August 13, 2021; Accepted for Publication: October 7, 2021)

\begin{abstract}
The purpose of this paper is a designing an efficient solar Photovoltaic Water Pumping System (PVWPS) by using a three phase induction motor. Two adaptive fuzzy logic controllers are proposed to control the dc-link voltage and the induction motor speed. A combination between of fuzzy logic and gainscheduling controller is proposed to design the adaptive Fuzzy Gain-scheduling Proportional and Integral (FGPI) controllers. A linearized model is considered for the system using small signal model. The performances of the PVWPS using the proposed controllers are set side by side to those gotten from the classic Proportional plus Integral (PI) controllers. The simulation results demonstrated that the suggested controllers are effective in enhancing the dynamic performance of the system.
\end{abstract}

KEYWORDS: Fuzzy logic control, PV system, induction motor, speed control, vector control.

\section{INTRODUCTION}

$\mathbf{E}$ nergy demand has increased significantly as a consequence of industrialization. The slow depletion of oil and coal has begun. On the other hand, traditional energy generation continues to increase greenhouse gas emissions. Nowadays the global task is reducing emissions of carbon dioxide and ensure safety, producing clean and economical energy, as well as achieving more sustainable energy systems (Santos, Antunes, Chehab, \& Cruz, 2006). Researchers have focused their attention on PV systems, which are promising as a good renewable energy source. Because there are no moving parts, solar energy is completely clean. Solar energy requires no maintenance, produces no pollution, and causes no noise (Szabó, 2017; Yu \& Chien, 2009). Photovoltaic Water Pumping System (PVWPS) is the most well-known application of PV-based standalone systems, particularly in areas with abundant solar radiation but no connection to national power networks.

Induction Motor (IM) is the most existing topologies of Photovoltaic Water Pumping System (PVWPS) for driving the pump due to the lack of a commutator and brushes. Hence, IMs are reliable, cost-effective, and free maintainable. In addition, IMs have light weight, low inertia, high efficiency and overload capacity (Ramesh, Vasavi, \& Sirisha, 2014).
However, IM, in general, are very nonlinear and have complex time-varying dynamics. As a result, the speed regulation of IM is a complicated matter in industry. For controlling IM, the basic goal is to keep the machine running efficiently and effectively (Krishnan, 2001).

Control techniques designed for $\mathrm{AC}$ drives and dc-link voltage provide a good chance to use the AC motor in PV systems. Conventional Proportional and Integral (PI) and fuzzy controllers are two controllers that have quite different properties and are both efficient for managing the dc-link voltage and an induction motor speed (Usha \& Subramani, 2018).

In (Ghosh, Ganesh Malla, \& Narayan Bhende, 2015), a model of the small-signal was obtained and a pair of PI controllers were designed to control the speed of IM and to regulate the dc-link voltage. The simulation outcomes clearly showed that the linearized system neatly illustrates the nonlinear system round the same working conditions and PI controllers realize desired performance and robustness. In (Tian, Loh, Deng, Chen, \& Hu, 2016), the PI controller achieved the modification of dc-link voltage. A significant improvement in dc helps to make the tracking error stable.

IM`s speed control is handled by incorporating non-linear properties, following recent advancements in smart controllers and 
high-power electrical devices. In (Arrouf \& Bouguechal, 2003; Bharti, Kumar, \& Prasad, 2019) and (Awdaa, Obed, \& Yaqoob, 2021), a PI controller was used to describe the Voltage/Frequency $(V / F)$ control of IM. The results showed that the $V / f$ control is able to maintain the voltage and the current ratio constant. In ( $S \& S, 2020)$ Simulink model was built to control the motor speed using PI controller. The time response of the controller was analysed and verified for load-connected multilevel inverter, hence the outputs were improved by minimizing the rise time, settling time and steady-state error of the inverter.

As an intelligent control method, Fuzzy Logic Control (FLC) is defined by its logical resemblance to a human operator (Castillo, Amador-Angulo, Castro, \& Garcia-Valdez, 2016). FLC is derived from expert knowledge. FLC uses only simple mathematical calculation to simulate the expert knowledge and provides good performance in controlling systems (Aggarwal, Rai, \& Kandpal, 2015). FLC's structure is altered based on its internal configuration elements such as fuzzy rules, fuzzification, and defuzzification blocks (M \& Kumar, 2021). The FLCs offer significant benefits over conventional controllers due to their ability to accommodate nonlinear control commands (Cervantes \& Castillo, 2015).

In (Akhila, Praveen Kumar, \& Isha, 2016), a technique for implementing a rule-based FLC for three-phase IM constant speed operation was proposed. Here, keeping the V/f ratio constant was the key element of the control strategy.

In (Errouha, Motahhir, Combe, Derouich, \& Ghzizal, 2019), an intelligent artificial speed control solution for IMs was presented to enhance the efficiency of the PV system. Also, the IM speed control based Direct Torque Control (DTC) with fuzzy PI control was presented. The simulation results showed that the PV water pumping system delivered fast and strong responses in terms of pumped water, tracking speed, flux and stator current.

A 3kW single phase grid-linked to PV system was presented in (Zeb et al., 2019) with a FLCPI to control the dc-link voltage and to design a controller that guarantees fast, robust, reliable, and efficient performance. In (Nannam \& Banerjee, 2021), a peak power controller and dclink voltage regulator based on a FLC were considered to track the PV source's peak power and to regulate the voltage across the capacitor.

Fuzzy system is computationally efficient and functions efficiently with linear and adaptive systems while gain-scheduling controllers are robust and also convenient to practical applications. Thus, in this paper fuzzy logic and gain-scheduling controller are combined to design Fuzzy Gain-scheduling Proportional and Integral (FGPI) controllers to control the induction motor speed and dc-link voltage. A PV based water pumping system without dc to dc converter (for MPPT) and battery is considered. The linearized system that derived in (Ghosh et al., 2015) is considered. The PVWPS controlled by the proposed controllers is tested using MATLAB/Simulink and MATLAB toolbox and the outcomes are compared to those obtained by using conventional PI controllers.

The entire research is ordered as: in Section 2, system components are modeled. In Section 3, conventional PI controller is developed and FGPI controller is provided in-depth. The results of the study are demonstrated in the Section 4. Lastly, Section 5 is the conclusion of this work. The DC-link voltage controller is designed in the continuous time domain. It

consists of P-I controller where the integral part reduces the steady state error of the DC- link voltage

\section{MATHEMATICAL MODEL OF PVWPS}

In order to utilize the sun's energy for generating power, one or more solar panels are used in PV systems, as well as an inverter and other electrical and mechanical components. Fig. (1 shows the PVWPS considered in this paper. The subsystems of the proposed system are linearized around an operating condition. The nonlinear model is linearized by applying small signal method and Taylor series expansion method to each block (Ghosh et al., 2015). 


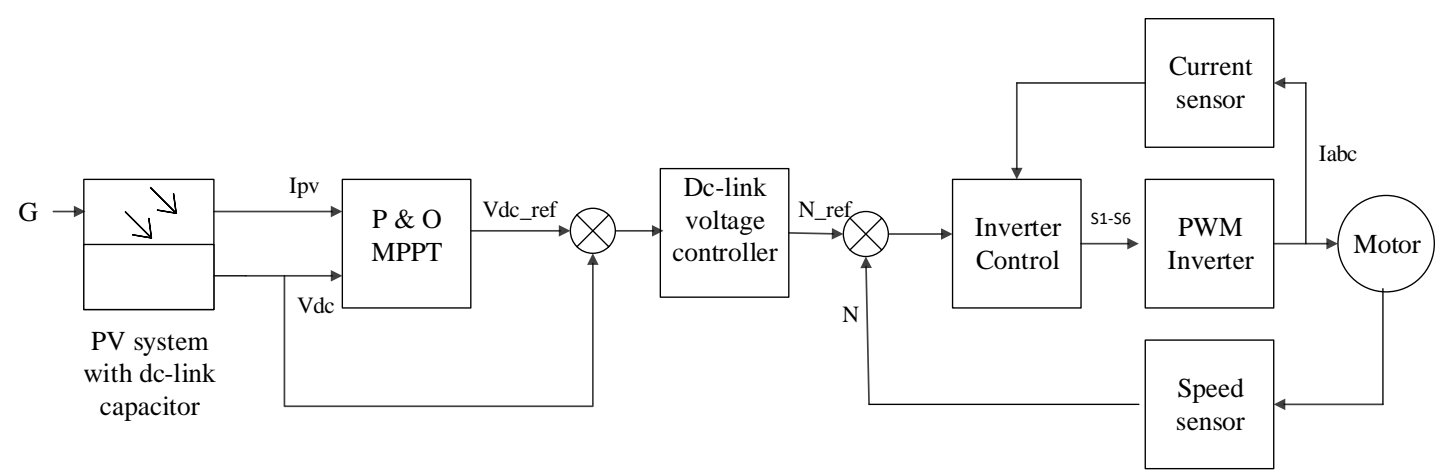

Fig. (1): PV Fed 3-Phase Induction Motor (Ghosh et al., 2015)

\subsection{Modelling of the PV Subsystem}

The PV subsystem is divided into photovoltaic cells and dc-link capacitor.

\section{A. PV system}

To enhance the PV's dc output to the appropriate value, series of solar cells are wired together. The most important goal of the PV array is to produce a dc voltage between its two terminals when they are well-lit by sunlight. The corresponding circuit of a PV cell (one diode practical pattern) is shown in Fig. (2.



Fig. (2): PV Module Equivalent Circuit

By applying Kirchhoff's current law:

$$
\begin{aligned}
& I=I_{p h}-I_{d}-I_{s h} \\
& I_{p h}=G \frac{I_{s c}}{G^{*}}
\end{aligned}
$$

where $I$ represents the PV module current, $I_{p h}$ is the PV module photocurrent, $I_{d}$ is the diode current, $I_{S C}$ is the module short circuit current, $G$ denotes to solar irradiance $\left(W / \mathrm{m}^{2}\right)$, $G^{*}$ denotes to the nominal irradiance and $I_{s h}$ is the shunt resistance current.

$I_{s h}=\frac{V_{D}}{R_{s h}}$

where $V_{D}=V+I R_{S}, R_{S h}$ and $R_{S}$ are the module's fundamental shunt and series resistances correspondingly and the value of $R_{S}$ is very small compared to $R_{s h}$.
The diode current $I_{d}$ is given by the Shockley`s diode equation:

$I_{d}=I_{o}\left(e^{\frac{V_{D}}{V_{t}}}-1\right)$

where $V_{t}$ is the PV module voltage and equal to $\overline{\mathrm{A}} K_{1} T n_{s} / q, q$ is the charge of electron and equal to $1.602 * 10^{-19} \mathrm{C}, K_{1}$ is Boltzmann's constant and equal to $1.3806 * 10^{-23} \mathrm{~J} / K, \overline{\mathrm{A}}$ is ideal factor of the p-n junction, $T$ is the temperature of the cell in $K, n_{s}$ is the solar cell number in the module and $I_{O}$ is the reverse saturation current of the diode.

In the PV subsystem, $\mathrm{G}$ is replaced by $\Delta G$, $I_{p h}$ by $\Delta I_{p h}$, and so on, the equation (4) is replaced by the gain, $\left(I_{0} / V_{t}\right) e^{\frac{V_{D}^{0}}{V_{t}}}$, relating $\Delta V_{D}$ and $\Delta I_{D}$ as demonstrated in Fig. (3. 


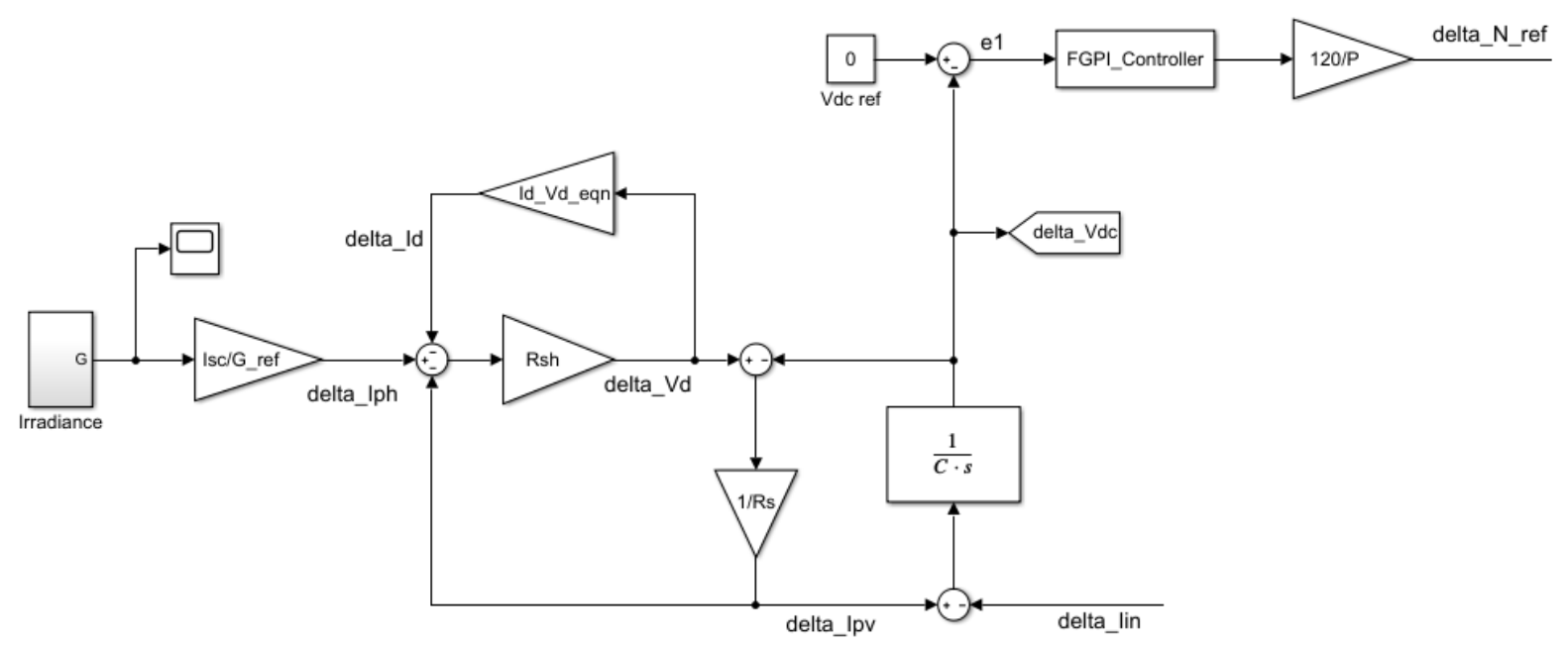

Fig. (3): Linearized PV Subsystem

The PV output is reliant on the amount of solar irradiation and the temperature of the sun. Solar energy generation can be maximum efficiency, by keeping a balance between load and PV generation. To keep the balance, it is imperative to ensure that the operating point of PV generation corresponds with the Maximum Power Point (MPP) (Basha, Rani, \& Odofin, 2018). As demonstrated in Fig. (1, the voltage of $\mathrm{PV}\left(V_{p v}\right)$ is equivalent to the dc-link voltage $\left(V_{d c}\right)$ because the PV module is linked to the $\mathrm{dc}$ bus. Hence, the voltage produced by $\mathrm{P} \& \mathrm{O}$ algorithm is handled as the indicated dc-link $\operatorname{voltage}\left(V_{d c}^{*}\right)$.

\section{B. Voltage Controller}

The dc-link voltage controller is used to control the dc-link voltage at a constant regular value irrespective of voltage ripple. In order to balance the input power from the PV panel with the average output power (see Fig. (3), the PV

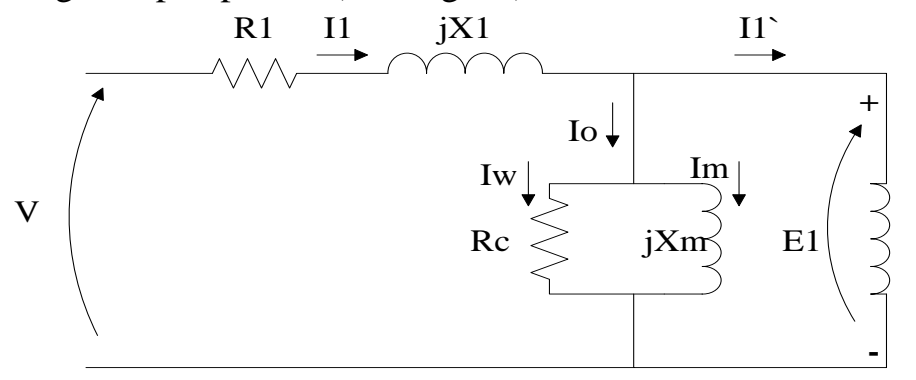

panel is connected to a loop-feedback that monitors the dc-link voltage (Tayebi, Shinde, Pepper, Hu, \& Batarseh, 2017).

The objective of using dc-link voltage controller in Fig. (1 is to fix the reference speed $\left(N^{*}\right)$ of the induction motor so that dc-link voltage $\left(V_{d c}\right)$ follows the voltage output of the MPPT $\left(V_{d c}^{*}\right)$. Since the change of irradiation is much more than the change of MPPT output voltage of dc-link, the effect of the MPPT is neglected in the linear system.

\subsection{Motor Subsystem}

$\mathrm{AC}$ induction motor is an unusual form of electrical motor that have a specific ideal features and performance in terms of starting, speed control, protections, and so on. The threephase IM is a rotating electrical machine that is considered to run on a three-phase source. The corresponding circuit of IM is shown in Fig. (4.

Fig. (4): Induction Motor Equivalent Circuit (Diyoke \& Aniagwu, 2016)

In Figure $4, \mathrm{~V}$ is supply voltage; $R_{1}$ and $X_{1}$ are the stator winding resistance and reactance respectively; $I_{1}, I_{o} I_{m}$ and $I_{w}$ are the stator current, , the stator no-load current, the magnetizing factor of no-load current and the working factor of no-load current respectively;
$X_{m}$ and $R_{c}$ are the exciting reactance and exciting resistance respectively; $I_{1}{ }^{\prime}$ is the current of rotor referred to stator side; $E_{2 s}$ and $E_{2}$ are the rotor induced emf at stand-still and under running condition respectively; $I_{2}$ is the rotor current, $R_{2}$ is the rotor winding resistance; and 
$X_{2 s}$ and $X_{2}$ are the rotor reactance at stand-still and the rotor reactance under running condition respectively.

The control of speed in IM motor is achieved by PWM switching of Voltage Source Inverter (VSI) while adjusting its DC bus voltage. The inverter controller employed is based on induction motor drive vector control. As illustrated in Fig. (1, the controller transfer pulse outputs $\left(S_{1} t o S_{6}\right)$ to the PWM inverter so that the real speed $(N)$ of the motor follows the reference speed $\left(N^{*}\right)$ make by the dc-link voltage controller.

The speed of the motor is

$\omega=\frac{1}{J} \int\left(T_{e}-T_{l}\right) d t$
$T_{e}=\frac{3}{2} \frac{P}{2} L_{m}\left(I_{q s} I_{d r}-I_{d s} I_{q r}\right)$

where $J$ is the moment of inertia, $T_{l}$ is the torque of the load, and $T_{e}$ is the electromagnetic torque developed as derived in (Ghosh et al., 2015).

In the induction motor drive vector control, the dynamics of PWM inverter with the PWM generator is ignored and the averaged instantaneous electromagnetic torque $T_{e}$ generated by the motor is same as averaged $T_{e}^{*}$ set by the PI controller of the vector control system as demonstrated in Fig. (5. As the torque of the load is constant, $\Delta T_{L}=0$, and as the output power of the motor $P_{0}=T_{e} \omega, \Delta P_{0}$ will equal to $\Delta T_{e} \omega^{0}+\Delta \omega T_{e}^{0}$.



Fig. (5): Linerized Motor Subsystem

\section{THE PROPOSED FUZZY CONTROLLER}

FLC is one of the most fascinating fields where fuzzy logic can be used. It has been shown that FLC is efficient for complex, nonlinear, and unspecific defined procedures that are impractical or impossible to control using standard model-based control techniques.

The three-stage procedure of FLC can be categorized into: fuzzification, inference, and defuzzification stages. The overall architecture of FLC is shown in Fig. (6. 


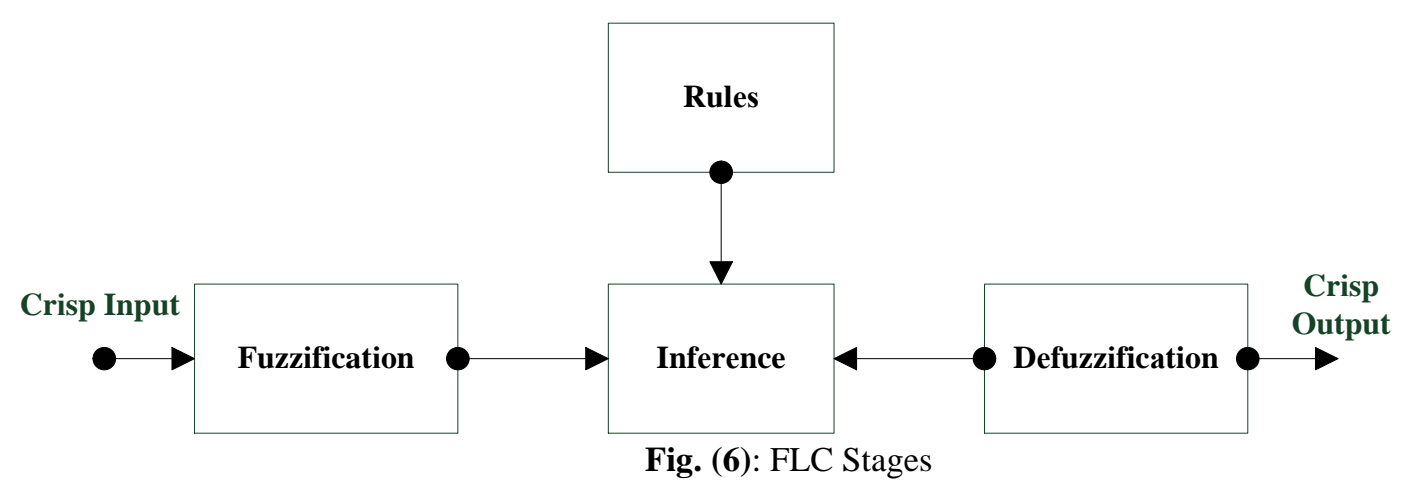

Fuzzification: Linguistic variables receive membership values assigned to the membership function.

Inference Method: Each rule has an output membership function that can be described as the minimum and maximum operators.

Defuzzification: Plants often require a nonfuzzy value of control, so they must go through a defuzzification stage. The output of the FLC is computed using the height method, and the FLC output is used to the control system output.

To recover the speed response, decrease the requirement to change parameters of IM and offer high robustness, Sugeno FLCs are used to

control the system.



Fig. (7 presents the complete system diagram with controllers. Where block (Id_Vd_eqn) represents Shockley`s diode equation (4).

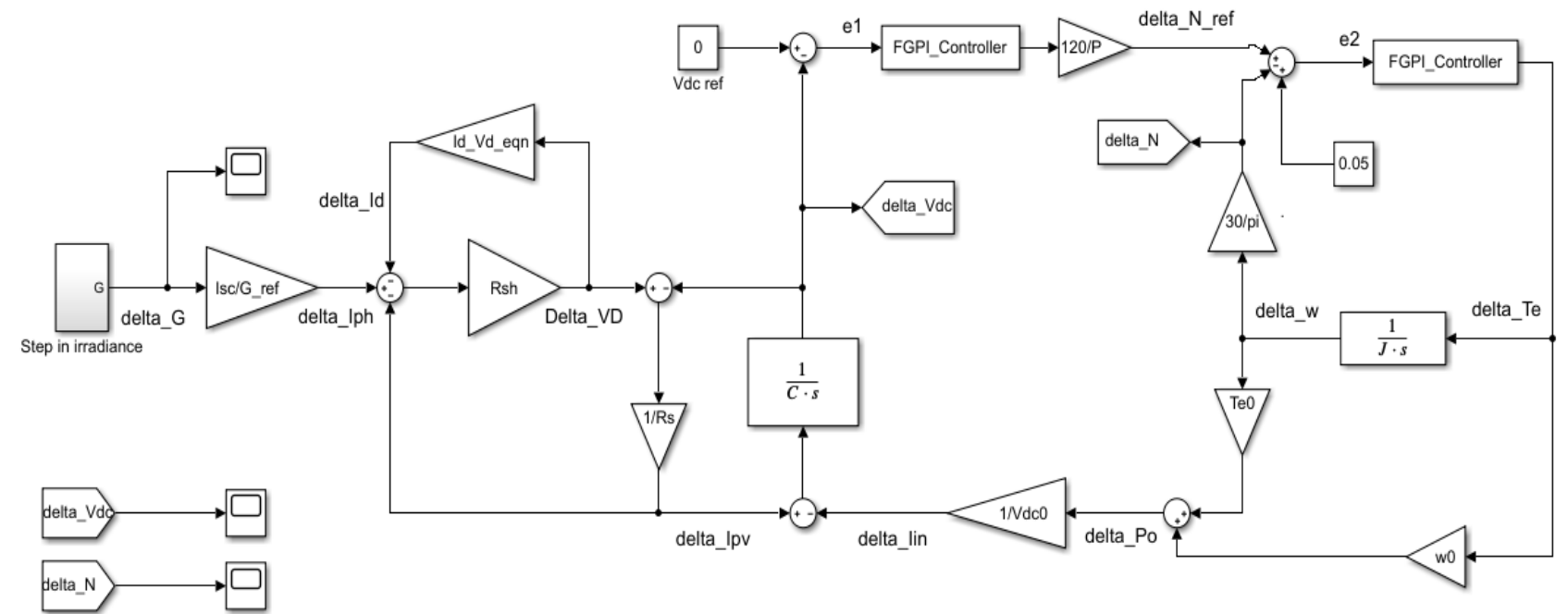

Fig. (7): Overall Linear Model with Fuzzy-PI controller

Sugeno fuzzy system is computationally efficient and works well with linear and adaptive techniques and very useful for mathematical analysis along with modelling nonlinear systems(Hassan, Moghavvemi, Almurib, Muttaqi, \& Du, 2012). The basic concept of 
Sugeno fuzzy models is that, there is a known global system which is non-linear, containing of subsets of linear models locally and linked smoothly through fuzzy sets' member functions. This concept aids to get reduction in fuzzy rules and provides different approach for extremely complex non-linear system. On other hand, gainscheduling controllers are robust and also convenient to practical applications. Hence, in this paper a FGPI controller is designed by combination of Sugeno fuzzy system and gainscheduling controller (Hassan et al., 2012) to implement two adaptive FLCs to control the dclink voltage and regulate the speed of IM. The output of a fuzzy system is obtained in term of a function as regards to the inputs.

The control structure can be written as:

$u(t)=K_{P} e+K_{I} \int \dot{e} d t$

where $e$ and $\dot{e}$ are the error and its derivative respectively, and $K_{P}$ and $K_{I}$ are the proportional and integral controller gains respectively.

For the proposed dc-link FGPI controller, input variables are the change of $V_{d c}$ error $\left(e_{1}\right)$ and its derivative error $\left(\Delta e_{1}\right)$. The controller output is the change in speed $(\Delta N)$

$e_{1}(k)=\Delta V_{d c}^{*}(k)-\Delta V_{d c}(k)$

$\Delta e_{1}(k)=e_{1}(k)-e_{1}(k-1)$

where $V_{d c}^{*}(k)$ is the indicated dc-link voltage, $\Delta V_{d c}(k)$ is the actual dc-link voltage, and $e_{1}(k-1)$ is the error value of previous sampling time.

In the case of motor speed control, the two needed input variables for the proposed FGPI controller are the error of motor speed $\left(e_{2}\right)$ and the derivative of error, which represents the change of speed error $\left(\Delta e_{2}\right)$. The controller output is the change in torque $(\Delta T)$.

$e_{2}(k)=\Delta N^{*}(k)-\Delta N(k)$

$\Delta e_{2}(k)=e_{2}(k)-e_{2}(k-1)$

where $N^{*}(k)$ is the reference speed, $\Delta N(k)$ is the actual rotor speed, and $e_{2}(k-1)$ is the value of error at previous sampling time.

The output of Sugeno fuzzy system is given in terms of a functional relation of the inputs. These rules can be typically written as (Hassan et al., 2012):

$$
\begin{aligned}
& \text { if } x_{1} \text { is } L_{j} \text { and } x_{2} \text { is } M_{j} \text { then } y_{j} \\
& =a x_{1}+b x_{2}+c \\
& =1,2, \ldots, p
\end{aligned}
$$

where $L, M$ are fuzzy sets; $x_{1}, x_{2}$ are the two inputs for fuzzy system; and $a, b$, and $c$ are constants.

In this paper, a zero-order Sugeno fuzzy (Singleton) model as the most commonly used model and meets the requirements of our problem. Therefore, the coefficients $(a$ and $b)$ in (12) are assumed to zero in order to obtain the Singleton type model.

In order to find the gains (i.e. $K_{P}$ and $K_{I}$ ), the fuzzy rules are generated by analysing the system's step response. Fuzzy logic rules for both gains are shown in Table 1 and Table 2.

Table (1): Fuzzy Logic Rules for $K_{P}$

\begin{tabular}{cccccccc}
\hline $\begin{array}{c}\text { Variation } \\
\text { in }\end{array}$ & \multicolumn{7}{c}{ E } \\
\cline { 2 - 8 } & NB & NM & NS & ZE & PS & PM & PB \\
\hline NB & B & B & B & B & B & B & B \\
\hline NM & S & M & B & B & B & M & S \\
\hline NS & S & M & M & B & M & M & S \\
\hline ZE & S & S & S & S & S & S & S \\
\hline PS & S & M & M & B & M & M & S \\
\hline PM & S & M & B & B & B & M & S \\
\hline PB & B & B & B & B & B & B & B \\
\hline
\end{tabular}

Table (2): Fuzzy Logic Rules for $\boldsymbol{K}_{\boldsymbol{I}}$

\begin{tabular}{cccccccc}
\hline $\begin{array}{l}\text { Variation } \\
\text { in E }\end{array}$ & \multicolumn{7}{c}{ E } \\
\cline { 2 - 8 } & NB & NM & NS & ZE & PS & PM & PB \\
\hline NB & S & S & S & S & S & S & S \\
\hline NM & S & M & M & B & M & M & S \\
\hline NS & M & M & B & B & B & M & M \\
\hline
\end{tabular}




\begin{tabular}{llllllll}
\hline ZE & B & B & B & B & B & B & B \\
\hline PS & M & M & B & B & B & M & M \\
\hline PM & S & M & M & B & M & M & S \\
\hline PB & S & S & S & S & S & S & S
\end{tabular}

Fuzzy membership functions and rules are considered to tune $K_{P}$ and $K_{I}$ of the controllers such that the fuzzy system functions as a "supervisor," to modify the parameters of the controller. The gains of the controllers are automatically modified following the changes in system operating conditions.

Triangle membership functions are used in this paper due to their ability to represent properly the professional knowledge and to shorten the computation procedure (Hassan et al., 2012). Seven fuzzy subsets are utilized: NB (Negative Big), NM (Negative Medium), NS (Negative Small), ZE (Zero), PS (Positive Small), PM (Positive Medium), and PB (Positive Big). The normalized input membership functions are defined

in

The values of $e_{1}$ and $\Delta e_{1}$ membership functions range from -6 to 6 and -2.5 to 3.5 , respectively. The values of $e_{2}$ and

$\Delta e_{2}$ membership functions range from -0.06 to 0.06 and -35 to 35 , respectively.

. Figures 9 and 10 show the fuzzy tunning rules for $K_{P}$ and $K_{I}$ parameters respectively.

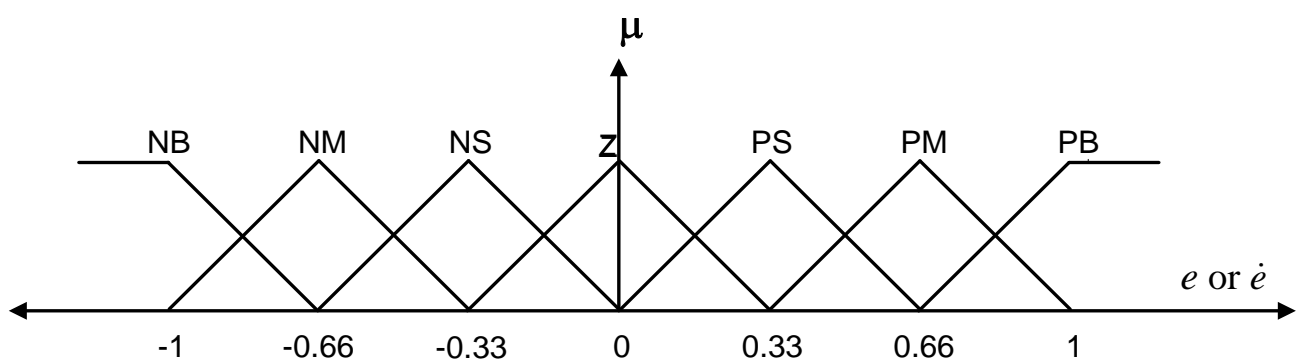

Fig. (8): Normalized Membership Function for the Proposed Controller



Fig/ (9): Three Dimensional Plot for Rule Base $\boldsymbol{K}_{\boldsymbol{P}}$ 


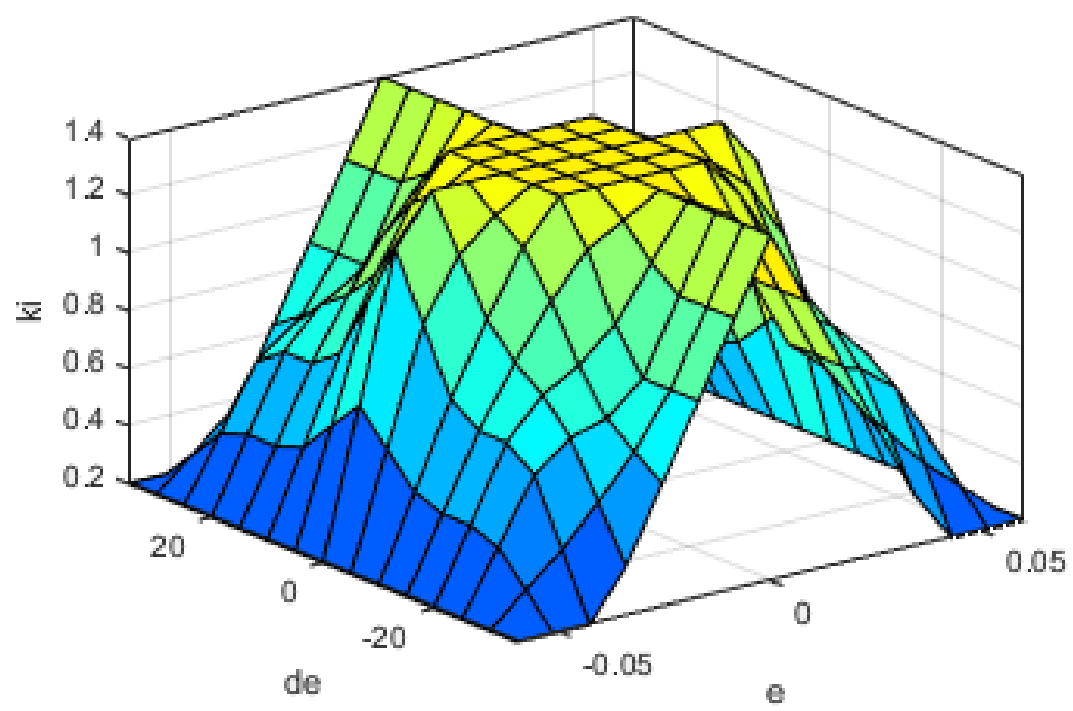

Fig. (10): Three Dimensional Plot for Rule Base $\boldsymbol{K}_{\boldsymbol{I}}$

The values of $e_{1}$ and $\Delta e_{1}$ membership functions range from -6 to 6 and -2.5 to 3.5 , respectively. The values of $e_{2}$ and $\Delta e_{2}$ membership functions range from -0.06 to 0.06 and -35 to 35 , respectively.

In the defuzzification process, singleton spikes are converted to a crisp values by using the Weight-Average (WA) method by determining the weighted average of these singletons (Negnevitsky, 2005).

\section{RESULTS AND DISCUSSION}

A $400 \mathrm{~W}$ PV array is designed to drive a 0.37 $\mathrm{kW}$ induction motor drive. The rating of PV array is selected more than the motor rating so that the performance of the motor remains unaffected by the losses incurred in the motor and converter. A PV array is designed by connecting $8 \mathrm{PV}$ modules in series of open circuit voltage $\left(\boldsymbol{V}_{\boldsymbol{o c}}\right)$ equals $21.1 \mathrm{~V}$ and 1 modules in parallel of short circuit current $\left(\boldsymbol{I}_{\boldsymbol{s c}}\right)$ equal to $3.2 \mathrm{~A}$, respectively. The specifications of PV module and IM used are given in Error! Reference source not found. and Error! Reference source not found. respectively.

Table (3): Solar Panel Design Parameters

\begin{tabular}{llll}
\hline Maximum Power & $\mathbf{5 0 ~ W}$ & Number of solar cells / module & 36 \\
\hline Number of solar cells in the array $\left(n_{s}\right)$ & 288 & Number of solar module in the array & 8 \\
\hline Short circuit current $\left(I_{s c}\right)$ & $3.2 \mathrm{~A}$ & Open circuit voltage $\left(V_{o c}\right)$ & $21.1 \mathrm{~V}$ \\
\hline Current at maximum power point $\left(I_{m p p}\right)$ & $3 \mathrm{~A}$ & Voltage at maximum power point $\left(V_{m p p}\right)$ & $16.7 \mathrm{~V}$ \\
\hline Series resistance $\left(R_{s}\right)$ & $0.675 \Omega$ & Shunt resistance $\left(R_{s h}\right)$ & $428.675 \Omega$ \\
\hline Diode ideality factor & 0.86315 & Standard Temperature & $25^{\circ} \mathrm{C}$ \\
\hline Temp. coefficient of $V_{o c}$ & $-0.3006^{\circ} \mathrm{C}$ & Temp. coefficient of $I_{s c}$ & $0.0102^{\circ} \mathrm{C}$ \\
\hline
\end{tabular}

Table (4): Induction Motor Parameters

\begin{tabular}{llll}
\hline Voltage $\left(\boldsymbol{V}^{\mathbf{0}}\right)$ & $\mathbf{3 8 0} \mathbf{V}$ & Power $\left(\boldsymbol{P}^{\mathbf{0}}\right)$ & $\mathbf{0 . 3 7} \mathbf{~ k W}$ \\
\hline Operating speed $\left(\omega^{\mathbf{0}}\right)$ & $140.32 \mathrm{rad} / \mathrm{s}$ & Moment of inertia $(\mathrm{J})$ & $0.0013 \mathrm{~kg} \cdot \mathrm{m}^{2}$ \\
\hline Stator resistance $\left(R_{s}\right)$ & $11.4 \Omega$ & Rotor resistance $\left(R_{r}\right)$ & $29.9 \Omega$ \\
\hline Stator inductance $\left(L_{I S}\right)$ & $0.0678 \mathrm{H}$ & Rotor inductance $\left(L_{I r}\right)$ & $0.0678 \mathrm{H}$ \\
\hline Mutual inductance $\left(L_{m}\right)$ & $0.734 \mathrm{H}$ & Number of poles $(\mathrm{P})$ & 4 \\
\hline
\end{tabular}

In the simulation, the nominal solar irradiance $\mathrm{G}^{*}=1000 \mathrm{~W} / \mathrm{m}^{2}$. The irradiance is decreased by $40 \%$ at $\mathrm{t}=3 \mathrm{sec}$ increased by $20 \%$ at $\mathrm{t}=4.5 \mathrm{sec}$, decreased by $10 \%$ at $\mathrm{t}=6 \mathrm{sec}$, then increased by $30 \%$ at $\mathrm{t}=7.5 \mathrm{sec}$ as shown in Fig.
(11. The simulation is carried out for the system through the proposed PGPI controllers. The obtained results are compared to those obtained in (Ghosh et al., 2015). 


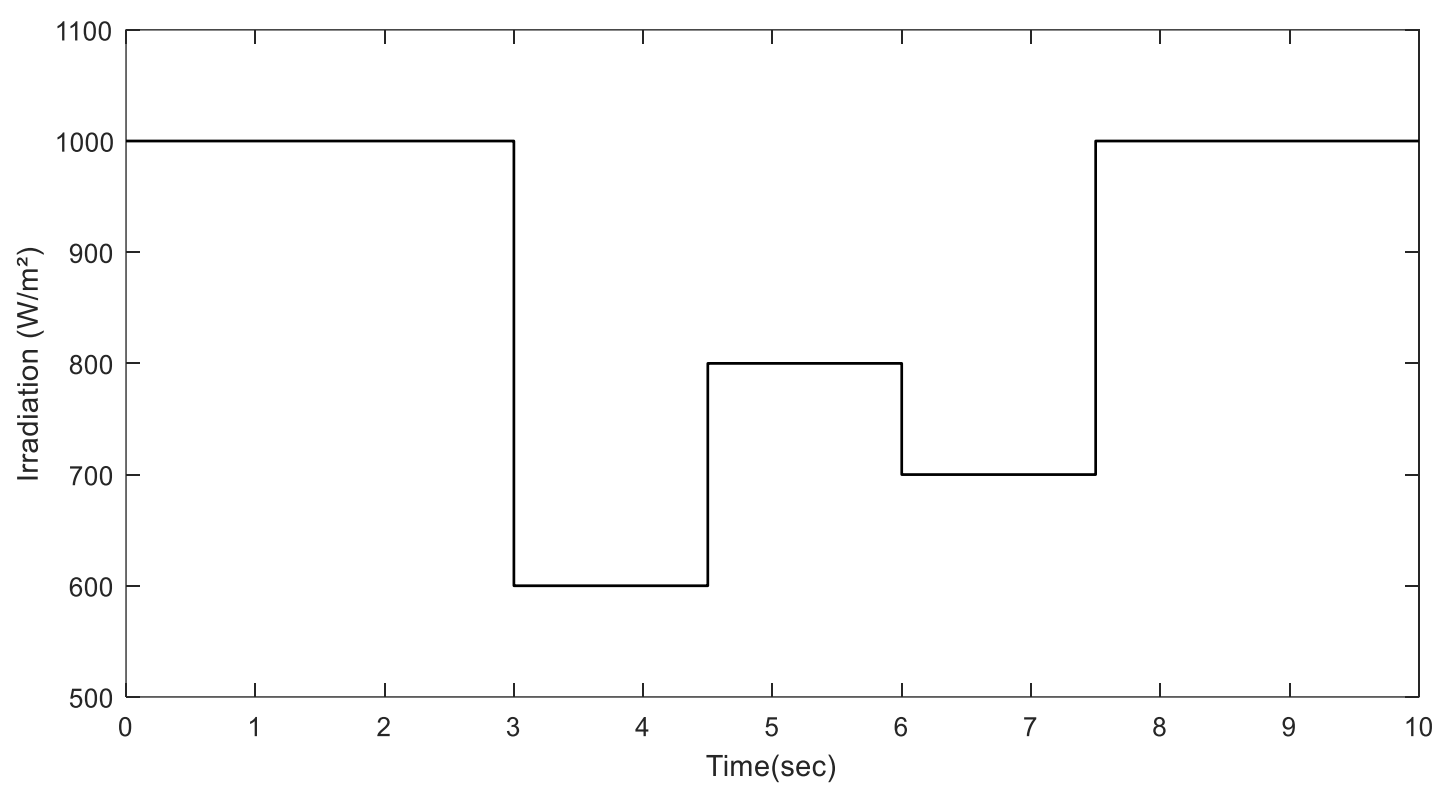

Fig. (11): Solar irradiance waveform

The system is tested under nominal operating condition and when the system is subjected to a disturbance.

\section{A. Under Nominal Operating Condition}

The responses of $\Delta V_{d c}$ and $\Delta N$ are obtained for the proposed FLC and PI controllers that seen in Fig. (12 and Fig. (13, respectively. The results showed that peak time and settling time of the speed and voltage controller are decreased by using the proposed controllers contrasted to the conventional PI controllers.
In Figure 12, for the first disturbance (i.e. $\mathrm{t}=$ $3 \mathrm{sec}$ ) the $\Delta V_{d c}$ response by using the proposed FGPI controller reach settling time in $0.6 \mathrm{sec}$ and peak time in $0.03 \mathrm{sec}$. However, by using PI controller the settling time and peak time of the response are $1.2 \mathrm{sec}$ and $0.1 \mathrm{sec}$ respectively. In Figure 13, $\Delta N$ response reach the settling time in $0.6 \mathrm{sec}$ and peak time in $0.5 \mathrm{sec}$ by using FGPI controller while settling time and peak time for the response based on PI controller are $1.5 \mathrm{~s}$ and $1.4 \mathrm{~s}$ respectively.

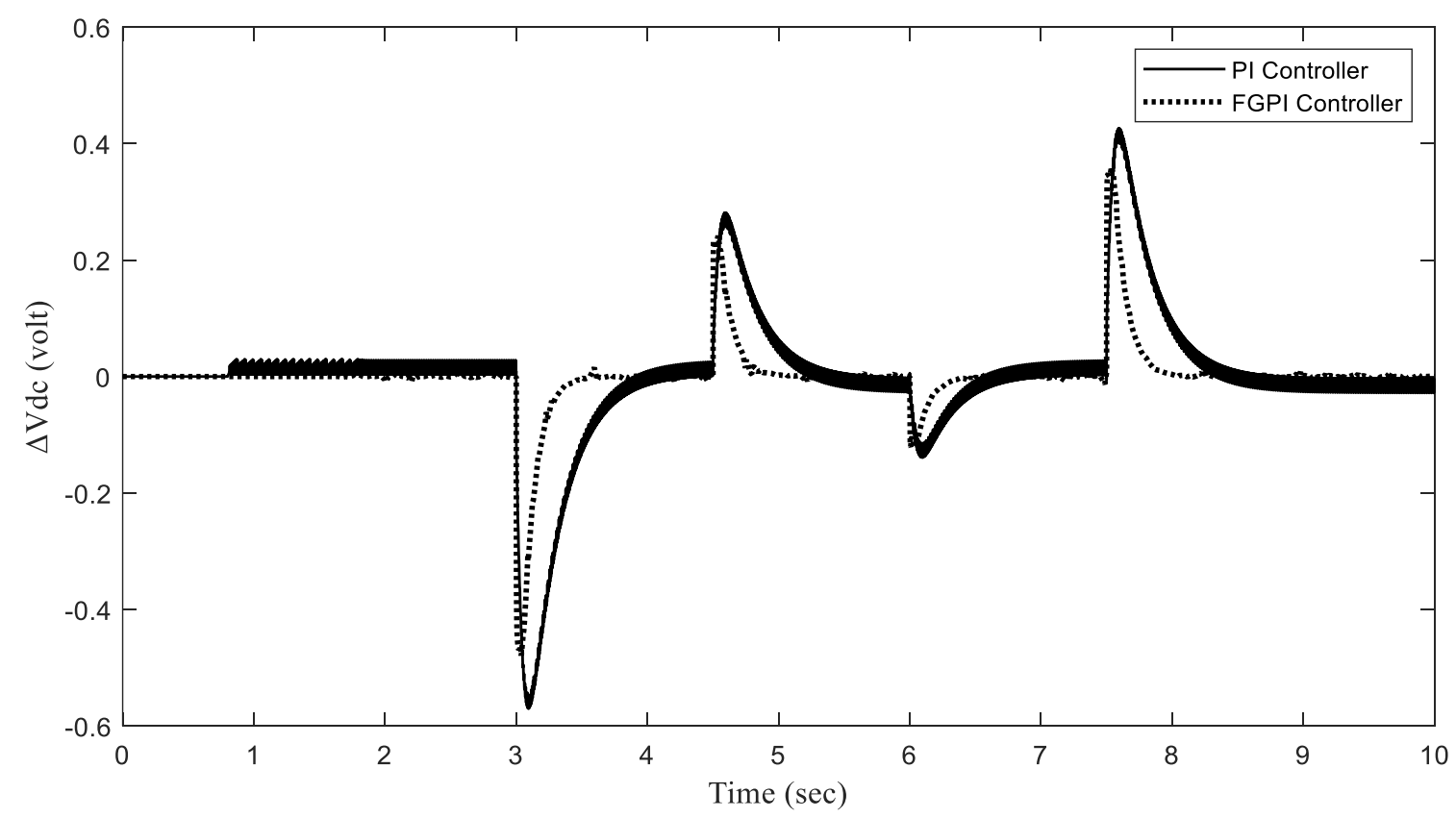

Fig. (12): DC-link Voltage Response 


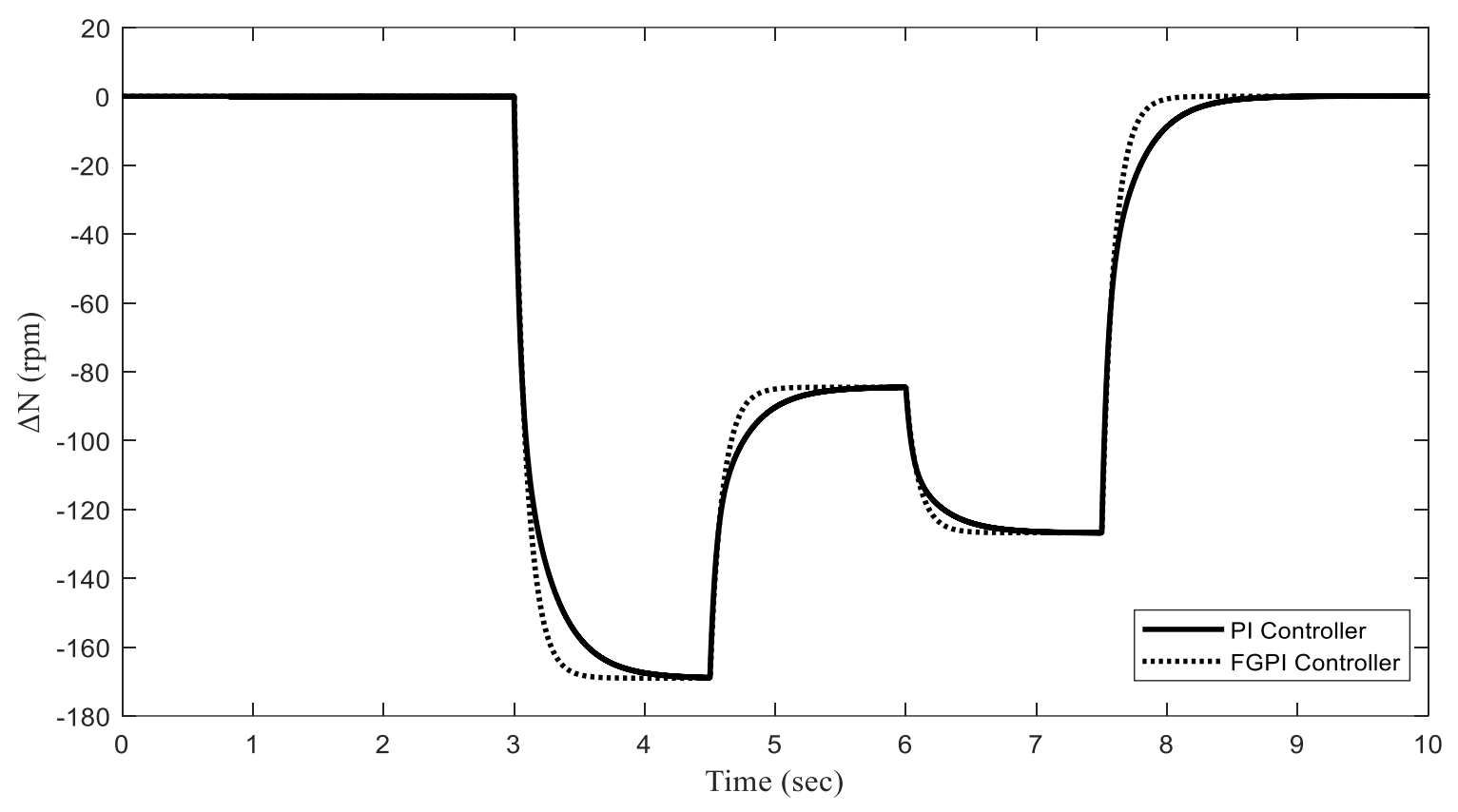

Fig. (13): Speed Response

\section{B. Under Disturbance Condition}

The system is subjected to 0.05 disturbances at speed junction. Here, the response when both outer loop and inner loop gains are halved is considered. The responses of $\Delta V_{d c}$ and $\Delta N$ are obtained for the proposed FGPI and PI controllers as seen in Figures 14-17. The results revealed that the speed and the dc-link voltage responses by using proposed controllers are improved in terms overshoot, peak time and settling time compared to the conventional controllers.
The settling time and peak time for the $\Delta V_{d c}$ response for the first disturbance by using the proposed FGPI controller are $0.7 \mathrm{sec}$ and 0.02 sec respectively (see Figure 14). However, by using PI controller the settling time and peak time are $1.3 \mathrm{sec}$ and $0.08 \mathrm{sec}$ respectively. In Figure 15, by using the proposed controller, the settling time and peak time of $\Delta N$ response are $0.8 \mathrm{sec}$ and $0.6 \mathrm{sec}$ respectively while settling time and peak time for the response, by using PI controller, are $1.5 \mathrm{sec}$ and $1.4 \mathrm{sec}$ respectively. 




Fig. (14): DC-link Voltage Response Following Disturbance

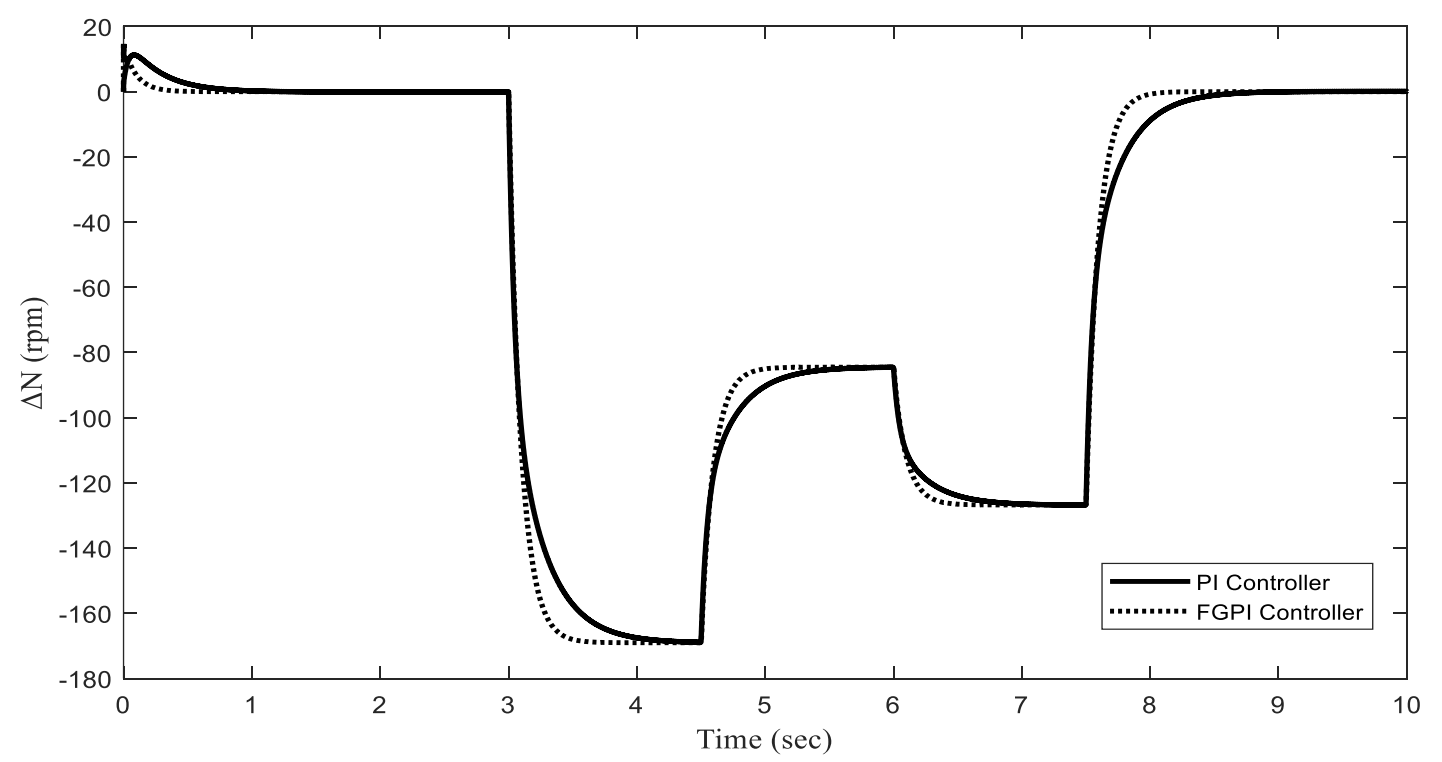

Fig. (15): Speed Response Following Disturbance 


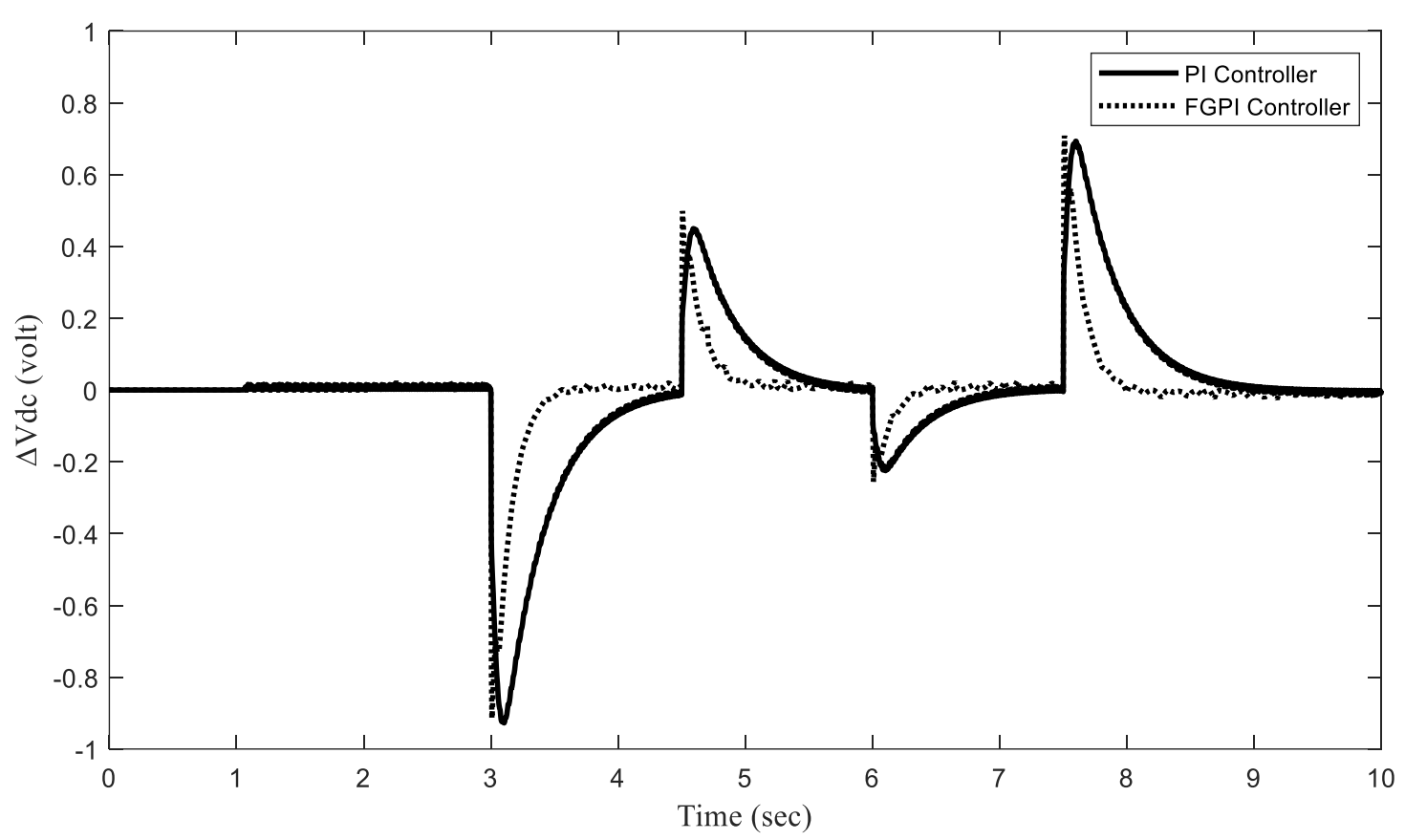

Fig. (16): Dc-link Voltage Response with Half Inner and Outer Loop Gains

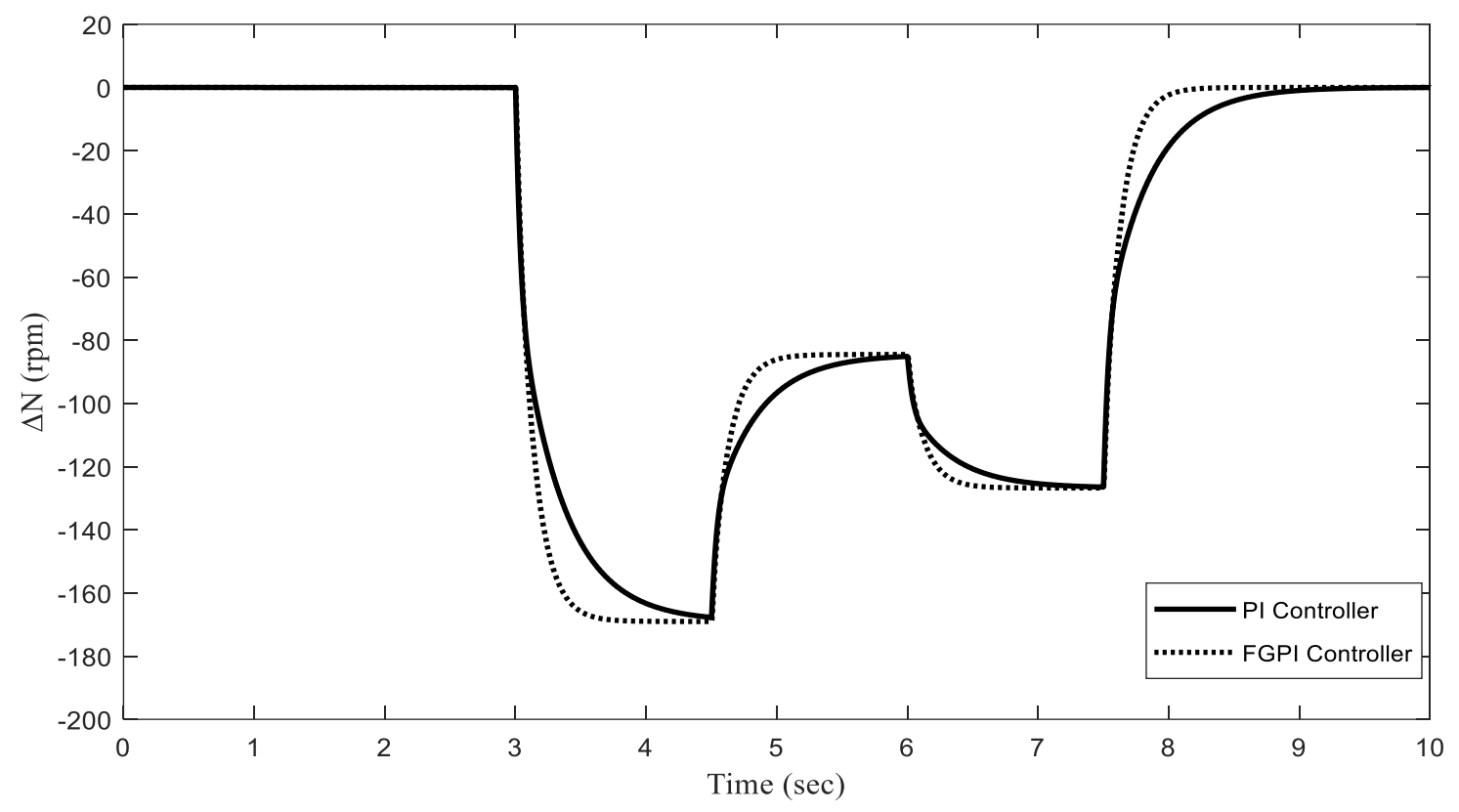

Fig. (17): Speed Response with Half Inner and Outer Loop Gains

From the above discussion, it can be concluded that by applying a proposed FGPI controllers, the speed and the dc-link voltage responses are improved compared to the conventional controllers. It's clear that under different operation conditions, the system response reach the peak time faster. Peak time is decreased using the proposed controller and the settling time is reduced compared to the results obtained by using the conventional controller. Thus, the overall system efficiency of the independent photovoltaic water pumping system can be improved by using the proposed fuzzy based control system.

\section{CONCLUSION}

Fuzzy Gain-scheduling Proportional and Integral controller (FGPI) was proposed to implement two fuzzy controllers to control the dc-link voltage and the speed of an induction motor. In this paper, Sugano fuzzy based model was utilized to design the controllers. The solar 
Photovoltaic Water Pumping System (PVWPS) based IM without battery storage has been proposed and its appropriateness has been presented. MATLAB/Simulink and MATLAB toolbox were used to analyse the different performance of the system. Simulation results showed that the designed FGPI controllers provide a good dynamic behaviour of the motor with a rapid settling time, no overshoot and had better performance than PI controllers. The post disturbance analysis of the simulation results illustrated the better tracking of reference value by using FGPI as compared to PI Controller. It can be concluded that the proposed controller can provide cost effective solution for the system. For future works, the proposed controller can be applied to an experimental system.

\section{REFERENCES}

Aggarwal, A., Rai, D. J., \& Kandpal, M. (2015). Comparative Study of Speed Control of Induction Motor Using PI and Fuzzy Logic Controller. 10, 2320-3331. doi: 10.9790/167610214352

Akhila, E., Praveen Kumar, N., \& Isha, T. B. (2016). Fuzzy Logic and PI Controls in Speed Control of Induction Motor. 397, 987-1001. doi: 10.1007/978-81-322-2671-0_93

Arrouf, M., \& Bouguechal, N. (2003). Vector control of an induction motor fed by a photovoltaic generator. Applied Energy, 74(1), 159-167. doi: 2619(02)00142-3 https://doi.org/10.1016/S0306-

Awdaa, M., Obed, A., \& Yaqoob, S. (2021). A Comparative Study between V/F and IFOC Control for Three-Phase Induction Motor Drives (Vol. 1105).

Basha, C. H., Rani, C., \& Odofin, S. (2018, 28-29 March 2018). Analysis and Comparison of SEPIC, Landsman and Zeta Converters for PV Fed Induction Motor Drive Applications. Paper presented at the 2018 International Conference on Computation of Power, Energy, Information and Communication (ICCPEIC).

Bharti, R., Kumar, M., \& Prasad, B. M. (2019, 30-31 March 2019). V/F Control of Three Phase Induction Motor. Paper presented at the 2019 International Conference on Vision Towards Emerging Trends in Communication and Networking (ViTECoN).

Castillo, O., Amador-Angulo, L., Castro, J. R., \& Garcia-Valdez, M. (2016). A comparative study of type-1 fuzzy logic systems, interval type-2 fuzzy logic systems and generalized type-2 fuzzy logic systems in control problems. Information Sciences, 354, 257-274. doi: https://doi.org/10.1016/j.ins.2016.03.026

Cervantes, L., \& Castillo, O. (2015). Type-2 fuzzy logic aggregation of multiple fuzzy controllers for airplane flight control. Information Sciences, 324, 247-256. doi: https://doi.org/10.1016/j.ins.2015.06.047

Diyoke, G., \& Aniagwu, U. (2016). Different Methods of Speed Control of Three-Phase Asynchronous Motor. doi: 10.12691/ajeee-42-3

Errouha, M., Motahhir, S., Combe, Q., Derouich, A., \& Ghzizal, A. E. (2019, 27-30 Nov. 2019). Fuzzy-PI Controller for Photovoltaic Water Pumping Systems. Paper presented at the 2019 7th International Renewable and Sustainable Energy Conference (IRSEC).

Ghosh, A., Ganesh Malla, S., \& Narayan Bhende, C. (2015). Small-signal modelling and control of photovoltaic based water pumping system. ISA Transactions, 57, 382-389. doi: https://doi.org/10.1016/j.isatra.2015.01.008

Hassan, L. H., Moghavvemi, M., Almurib, H. A. F., Muttaqi, K. M., \& Du, H. (2012). Damping of low-frequency oscillations and improving power system stability via auto-tuned PI stabilizer using Takagi-Sugeno fuzzy logic. International Journal of Electrical Power \& Energy Systems, 38(1), 72-83. doi: https://doi.org/10.1016/j.ijepes.2011.12.022

Krishnan, R. (2001). Electric Motor Drives: Modeling, Analysis, and Control.

M, S., \& Kumar, D. (2021). Fuzzy Based MPPT Controller For Solar Photovoltaic Systems. International Journal of Advanced Research in Science, Communication and Technology, 359-370. doi: 10.48175/IJARSCT-1095

Nannam, H., \& Banerjee, A. (2021). A novel control technique for a single-phase grid-tied inverter to extract peak power from PV-Based home energy systems.

Negnevitsky, M. (2005). Artificial Intelligence A Guide to Intelligent Systems (2nd ed.): Addison-Wesley.

Ramesh, G., Vasavi, K., \& Sirisha, S. L. (2014). Photovoltaic Cell Fed 3-Phase Induction Motor Using MPPT Technique. International Journal of Power Electronics and Drive Systems (IJPEDS), 5. doi: 10.11591/ijpeds.v5i2.6209

S, C., \& S, D. (2020). PV-Based Multilevel InverterFed Three-Phase Induction Motor with Improved Time and Speed of Response (pp. 173-183).

Santos, J. L., Antunes, F., Chehab, A., \& Cruz, C. (2006). A maximum power point tracker for PV systems using a high performance boost converter. Solar Energy, 80(7), 772-778. doi: https://doi.org/10.1016/j.solener.2005.06.014 
Szabó, L. (2017, 6-9 June 2017). The history of using solar energy. Paper presented at the 2017 International Conference on Modern Power Systems (MPS).

Tayebi, S. M., Shinde, S., Pepper, M., Hu, H., \& Batarseh, I. (2017, 1-5 Oct. 2017). Implementing synchronous DC link voltage control with phase skipping on a three-phase microinverter using minimum DC link capacitance. Paper presented at the 2017 IEEE Energy Conversion Congress and Exposition (ECCE).

Tian, Y., Loh, P. C., Deng, F., Chen, Z., \& Hu, Y. (2016). DC-Link Voltage CoordinatedProportional Control for Cascaded Converter With Zero Steady-State Error and Reduced System Type. IEEE Transactions on Power Electronics, 31(4), 3177-3188. doi: 10.1109/TPEL.2015.2444386

Usha, S., \& Subramani, C. (2018). An Efficient Fuzzy Controller Design for Parallel Connected Induction Motor Drives. Journal of Physics: Conference Series, 1000, 012077. doi: 10.1088/1742-6596/1000/1/012077

Yu, T., \& Chien, T. (2009, 2-5 Nov. 2009). Analysis and simulation of characteristics and maximum power point tracking for photovoltaic systems. Paper presented at the 2009 International Conference on Power Electronics and Drive Systems (PEDS).

Zeb, K., Islam, S. U., Uddin, W., Ullah, K., Asghar, R., Busarello, T. D. C., \& Kim, H. J. (2019, 23 Dec. 2019). DC-link Voltage Regulation of Single-Phase Grid- Tied PV System using Fuzzy-PI Controller. Paper presented at the 2019 15th International Conference on Emerging Technologies (ICET). 